\title{
Investigation of the Effect of Building-Based Assessment on Flood Hazard Evaluation
}

\author{
Zeynep Ö. Kurt ${ }^{1 *}$, Murat Kankal², Ömer Yüksek ${ }^{3}$ \\ ${ }^{1}$ Civil Engineering Department, Erzincan Binali Yıldırım University, Turkey \\ ${ }^{2}$ Civil Engineering Department, Bursa Uludağ University, Turkey \\ ${ }^{3}$ Civil Engineering Department, Karadeniz Technical University, Turkey
}

Received: 30 September 2020

Accepted: 18 April 2021

\begin{abstract}
The aim of this study is to investigate the effect of building-based assessment on flood hazards. Değirmendere, which is one of the most important basins of the Eastern Black Sea Region of Turkey, was selected as the study area. Flood hazards for discharge values with different return periods of this region were found using; the damage percentages table recommended by the Huntington Civil Engineers Association (HCEA), the Van Eck and Kok depth-loss curves, and the equation obtained by Pistrika and Jonkman. The calculations were performed both for building-based and for the region-based and compared. Furthermore, the damage rates obtained for each building on a building-based were graded and shown on the map. It was determined that the damage on individual building-based estimation for Q1,000 calculated more than to the one on region-based $154 \%$ and $17 \%$ for the damage percentages table recommended by the HCEA, Van Eck and Kok depth-loss curves, respectively. Otherwise, it gave $11 \%$ less damage estimation for the equation obtained by Pistrika and Jonkman. Furthermore, it was concluded that the increase in damage from $\mathrm{Q}_{50}$ to $\mathrm{Q}_{100}$, from $\mathrm{Q}_{100}$ to $\mathrm{Q}_{500}$, and from $\mathrm{Q}_{500}$ to $\mathrm{Q}_{1,000}$ was between 16\%-30\% according to building-based damage estimation.
\end{abstract}

Keywords: Flood Hazard, Return Period, Değirmendere Basin, Damage Rating

\section{Introduction}

A flood is an event in which a stream overflows its bed due to various reasons and creates a magnitude of flow that will disrupt the normal socioeconomic life in the impact region by damaging the surrounding lands, settlements, infrastructure facilities, and living

*e-mail: zterzioglu@erzincan.edu.tr creatures. For the estimation of flood hazard, the area where the flood has spread is detected and the data of this area are determined. Afterward, the hazard model is selected based on the available data obtained. Flood depth is mostly used in flood hazard models because depth is both the most important and easily measurable parameter. Of course, depth is not the only parameter affecting the damage; there are also many other parameters. One of these parameters is flood velocity. The pressure force to which buildings will be exposed increases as the flood velocity increases. The flood 
duration, rate of its rise, and the pollution rate are also important parameters. Due to difficulties in obtaining the parameters affecting flood hazards, most of the methods proposed for damage calculation in previous studies were based only on the depth parameter [1-11]. Besides the depth, the flood velocity was also used in some studies $[12,13]$. In the world, some damage estimation curves and equations were created using the data obtained after the flood. While Prettenthaler et al. [5], Jongman et al. [7], Pistrika et al. [10], and McGrath et al. [11] attempted to establish the relationship between the variables by examining the relationship between damage and depth using the data of the floods. Prettenthaler et al. [5], determined the maximum damage potential of a flood in Europe using Geographic Information System and estimated the depth-dependent flood damage curve for residences. Jongman et al. [7] evaluated seven different flood damage models in terms of quality and quantity. They studied two cases of past floods in Germany and United Kingdom and concluded that qualitative analysis modeling approaches were very variable and in these results, depth damage functions were very sensitive to uncertainty. Pistrika et al. [10] designed the depth-damage function using data obtained from a flood in Moschato, a suburb of Athens, Greece in 2002. McGrath et al. [11], using data from the flood that occurred in Fredericton in 2008 presents results from a series of flood risk analyses to illustrate the sensitivity that can be associated to the depthdamage function, flood level, and restoration duration and to identify their relative impacts on the resulting losses. Kreibich et al. [12] and Pistrika and Jonkman [13] examined the relationship between damage, depth and velocity, and Lee and Kim [14] examined the relationship between precipitation intensity, duration, and damage. Kreibich et al. [12], investigated the effect of flood velocity and flood depth on the flood damage in 2002 in the Elbe Basin in Germany. They concluded that the energy height is a suitable flood impact parameter. Pistrika and Jonkman [13], proposed an approach based on the depth and velocity of the flood by analyzing a general dataset containing information about the economic damage levels of 95,000 homes in New Orleans after hurricane Katrina that occurred in 2005. Lee and Kim [14], divided the Sintaein Basin in Korea into sub-areas and obtained the damage functions for each area using the flood volume and damage data, and determined the rainfall intensity, duration and damage graph. Zin et al. [15], by conducting a survey in Myanmar's Bago River Basin to determine the economic damage caused by the flood in 2011; created the damage function depending on revenue loss, flood duration, job category, and household level, in addition to flood depth, landslide formation, and construction material types. Due to the difficulty in obtaining the data, detailed studies have not been conducted in this way to date in Turkey. The studies conducted in Turkey [16-19] were based on depth-dependent damage methods, usually obtained for different countries.
Serencam [16], made estimates about the damages and vulnerability of buildings in the event of floods that recur for 100 years and 500 years, depending on the flood depth obtained with the HEC-RAS program in the Sanayi District of the Değirmendere Basin in Trabzon. It has been calculated between 11.797.004-14.008.943 TL in floods within 100 years of repetition, and between 19.685.585-20.622.994 TL in floods within 500 years of repetition year of 2013. Yeğin [17], calculated the flood depths of the Salkım Creek in the Euphrates-Tigris Basin using the HEC-RAS program and calculated the damage using the HOWAS damage function. Girayhan [18], calculated the amount of flood damage repeating 100 years and 500 years depending on the depth of the flood in Terme. According to the calculation made in 2015, the amount of damage for 100 years of repetition is $85.520 .000 \mathrm{TL}$ and the amount of damage for 500 years is 95.090.000 TL. Taş et al. [19], calculated the areas to be inundated and the water levels of Akarçay Afyon Sub-Basin using HEC-RAS software for different repetitive flood flow rates. After that; They made flood damage estimates for different recurring flow rates $\left(\mathrm{Q}_{2}, \mathrm{Q}_{10}, \mathrm{Q}_{100}\right.$ and $\left.\mathrm{Q}_{500}\right)$ using average depth and depth-damage curves in previous studies. At the end of the study, they determined that the economic damage increased approximately four times from $Q_{2}$ to $\mathrm{Q}_{10}$, and approximately two times from $\mathrm{Q}_{10}$ to $\mathrm{Q}_{100}$ and from $\mathrm{Q}_{100}$ to $\mathrm{Q}_{500}$.

Floods are natural disasters that cause most economic losses after earthquakes in Turkey. In Turkey, floods cause an average of 100 million dollars of damage per year, whereas flood investments are an average of 30 million dollars per year [20].

There have been dozens of long disasters in the Eastern Black Sea Basin (EBSB), and loss of life and property has occurred. A total of 614 people died and 19 people disappeared in 42 different floods, landslides and floods that occurred in the EBSB during 86 years from 1929 to August 2015 [21].

This study, was aimed to investigate the effect of building-based assessment on flood hazard. For this purpose, unlike other studies, both building-based and region-based calculations were made. In this context, Değirmendere, which is one of the most important subbasins of the EBSB of Turkey was selected. In order to estimate the flood hazard rates; Huntington damage percentages [16] and Van Eck and Kok depth-loss curves [22] which are based on the depth parameter, and Pistrika and Jonkman [13] method, which is based on both depth and velocity parameters, were used. With these methods used, the damage rates that might occur were determined by obtaining the data of flood depth and flood velocity to which each building would be exposed in possible floods with different return periods. Furthermore, the damage rates were determined by considering the region-based, and they were compared by a building-based calculation. Moreover, the effects of floods with different return periods $\left(\mathrm{Q}_{50}, \mathrm{Q}_{100}, \mathrm{Q}_{500}\right.$, and $\mathrm{Q}_{1000}$ ) on damage rates were also examined. According 
to the knowledge of the authors, no study on buildingbased flood hazard estimation has been previously carried out in Turkey.

The study area, data and methodology are presented in Section 2. In Section 3, the results and discussion are given. Lastly, the conclusion part appears in Section 4.

\section{Experimental}

\section{The Study Area}

Turkey consists of 26 hydrological basins. With an average precipitation height of $1,198 \mathrm{~mm}$, the EBSB is the basin in Turkey that receives the most precipitation. The EBSB, which has an area of $24,077 \mathrm{~km}^{2}$, provides $9.5 \%$ of Turkey's total flow. This basin has an average flow height of $753 \mathrm{~mm}$ per year. When the precipitation heights of the provinces in the basin are examined, the highest average precipitation is in Rize with 2,299 $\mathrm{mm}$. Rize is followed by Giresun with 1,286 mm, Ordu with $1,038 \mathrm{~mm}$, and Trabzon with $820 \mathrm{~mm}$. The province with the least amount of precipitation in the basin is Gümüşhane with a value of $462 \mathrm{~mm}$. Precipitation values increase towards the most eastern part of the basin. For example, among the eastern most districts, precipitation heights of Arhavi and Hopa are 2,593 mm and 2,500 $\mathrm{mm}$, respectively $[23,24]$.

The Değirmendere Basin, which is the largest river basin within the provincial borders of Trabzon and located in the north of the Eastern Black Sea Mountains, has an area of $1,053 \mathrm{~km}^{2}$. This basin is located between $39^{\circ} 33^{\prime}-39^{\circ} 45^{\prime}$ east meridians and $40^{\circ} 32^{\prime}-40^{\circ} 54^{\prime}$ north latitudes [25].

The Değirmendere Basin is within the Eastern Black Sea sub-climate type of the Black Sea climate and fully reflects the climatic characteristics of the EBSB. The average annual temperature is $14.5^{\circ} \mathrm{C}$, and the average annual precipitation is $833.3 \mathrm{~mm}$. Precipitation generally has a uniform distribution in all seasons and varies between $650-900 \mathrm{~mm}$ on the coasts and $600-800 \mathrm{~mm}$ in the valleys facing the coast. The highest precipitation occurs in April-May and OctoberNovember-December [25].

In Değirmendere Basin, snow and rainwater that cannot leak into the soil on steeply sloping topography immediately start to flow due to the effects of snow melting and excessive local precipitation. The materials carried by the effect of the fast-flowing water lead to significant losses of life and property by completely or partially destroying or demolishing everything it hits (human, plant, animal, road, bridge, building, factory, car, etc.) [16].

\section{Data}

The flood inundation maps showing the water depth of the region where the Değirmendere Basin pours into the sea, and velocity maps, another outputs of flood modeling, were obtained from General Directorate the State Hydraulic Works (DSI). The maps were created using the SOBEK213 Program for flood flow rates with 50,100, 500, and 1,000-year return periods. Flood depths and velocities were determined for each building exposed to flood from these maps using the ArcMap 10.3 software. Also, with the help of the measure distance and area button in Google Earth, each floor area of each of these buildings has been calculated.

The hydrological method for the study area is first determined for the creation of flood maps. Afterward, flood hydrographs are obtained by making calculations according to this method. These flood hydrographs are entered into the integrated $(1 \mathrm{~B} / 2 \mathrm{~B})$ hydraulic model in the SOBEK 213 program, and the flood inundation areas and flood hazard maps are created.

A Digital Elevation Model (DEM) is created to represent the topography in each project area for flood studies. While DEM is being produced, 1/1000 scaled maps taken from the land and existing maps prepared by the relevant institutions in the project area are used. Existing buildings and roads are defined in GIS environment in layers and overlapped in DEM. It is necessary to define boundary conditions in model simulations. In addition, Manning roughness coefficients are also determined according to the terrain condition. (Turan et al., 2016). In order to create flood maps, the hydrological method suitable for the study area is determined first. Then, flood hydrographs are obtained by calculating according to this method. These flood hydrographs are entered into the integrated $(1 \mathrm{~B} / 2 \mathrm{~B})$ hydraulic model in the SOBEK Program, and flood spread areas and flood hazard maps are created. In obtaining the required peak flow rates; DSI Synthetic Method was used for Değirmendere Creek, since the precipitation area is approximately $1,000 \mathrm{~km}^{2}$ and the rise time of the unit hydrograph is longer than 2 hours. The area of precipitation was $1,047 \mathrm{~km}^{2}$. The maximum flow rate values obtained by DSI with DSI synthetic method were $462.85 \mathrm{~m}^{3} / \mathrm{sec}$ for Q50, $551.90 \mathrm{~m}^{3} / \mathrm{sec}$ for Q100, $733.30 \mathrm{~m}^{3} / \mathrm{sec}$ for Q500, and $811.42 \mathrm{~m}^{3} / \mathrm{sec}$ for Q1,000 [26].

\section{Methodology}

Depending on the flood depth and velocity obtained for each building, damage percentages were calculated using table by the Huntington Civil Engineers Association (HCEA), the Van Eck and Kok depthloss curves, and the equation obtained by Pistrika and Jonkman. In these estimations, since the damages that might occur when the depth was below $0.3 \mathrm{~m}$ in the HCEA method were neglected, the damages that might occur for the depths below $0.3 \mathrm{~m}$ were neglected in all damage estimations.

The estimated flood damage percentages obtained were graded in 5 classes as $0-15 \%, 16-30 \%, 31-45 \%$, $46-60 \%$, and $61-75 \%$. Since more than $75 \%$ amount of damage was not obtained, the value greater than $75 \%$ 
was not taken into consideration in the rating. These ratings were shown on the Google Earth map for each building in the section of the study area where the damage was most intense.

Afterward, the damage percentages obtained by each method of each building and the floor area were multiplied in order to calculate building areas that would be damaged on a building basis. The damage percentages obtained by each method depending on the average flood depth and velocity were multiplied by the sum of the floor areas of all buildings exposed to flood in order to perform regional calculations.

By considering the settlement in the region, each building was considered as the $3^{\text {rd }}$ class A group buildings (houses, commercial buildings, shopping malls, kindergartens, etc.) according to the unit price list published in the Official Gazette [27] dated March 16, 2019, by the Ministry of Environment and Urbanisation. The depreciation rate was considered to be $20 \%$ according to the Official Gazette dated 02.12 .1982 and numbered 17,886 by considering that the buildings in the study area were generally steel carcasses or reinforced concrete carcass structures and aged 16-20 years.

Moreover, the costs of the damages to which buildings would be exposed on a building and regional basis were obtained and compared by multiplying the building areas to be damaged by the unit price and depreciation. The flow chart of the study is briefly summarized in Fig. 1.

\section{Huntington Civil Engineers Association Damage Percentages}

The damage percentages used for damage estimation in buildings and obtained as a result of the study conducted by the HCEA in 1976 depending on flood depth are presented in Table 1.

In the HCEA method, damage percentages are obtained according to flood depth by taking into account the number of floors of buildings and whether they have basements. If the depth values were between the values indicated in Table 1, damage percentages were found by performing interpolation.

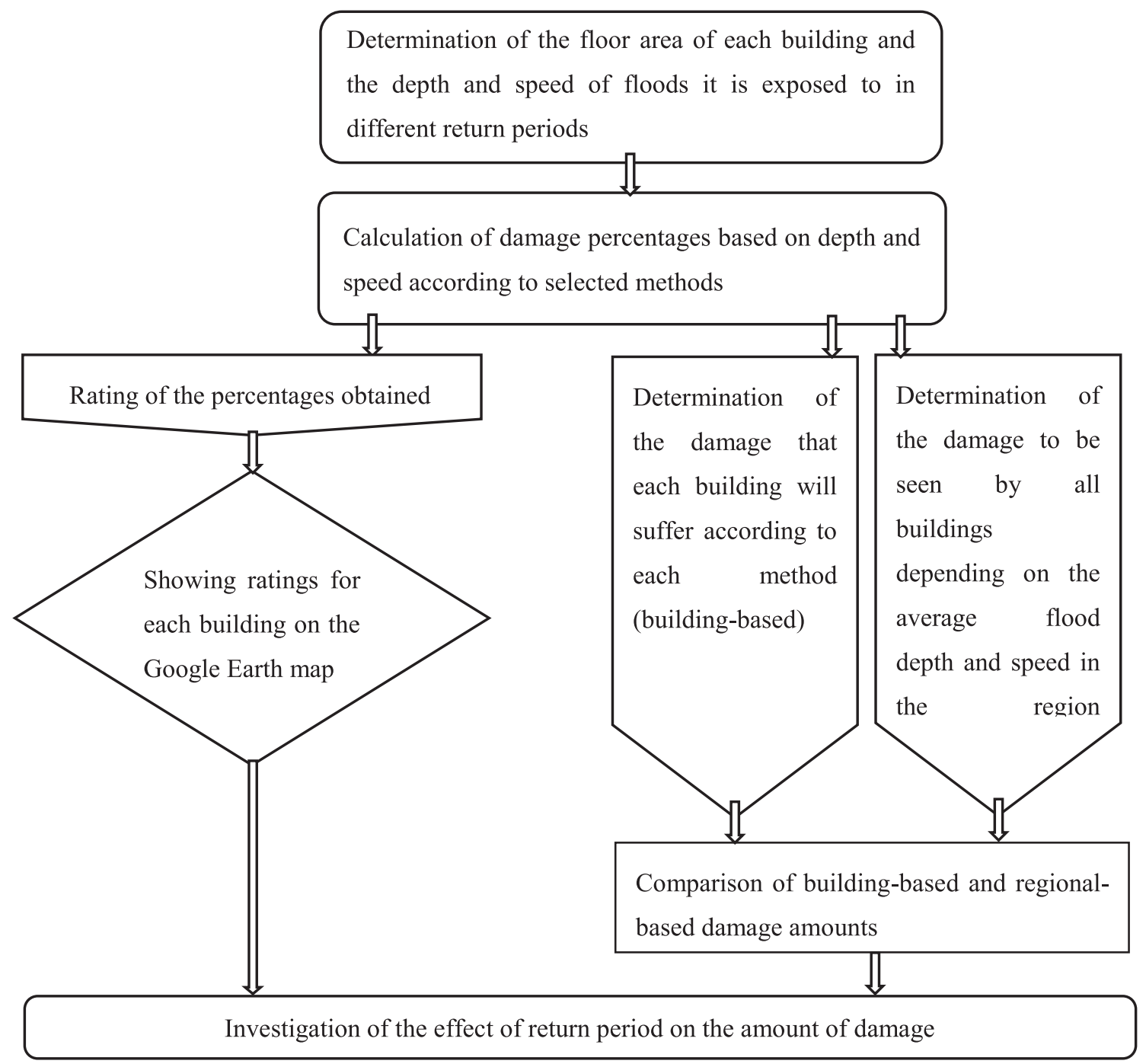

Fig. 1. Flow chart of this study. 
Table 1. The Huntington Civil Engineers Association depth-damage data [16].

Damage percentages (\%) according to flood depths (m)

Depth

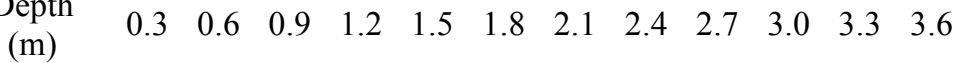

LAND USE

\begin{tabular}{|c|c|c|c|c|c|c|c|c|c|c|c|c|c|}
\hline $\begin{array}{l}\text { Single-storey } \\
\text { basement }\end{array}$ & & 8 & 17 & 31 & 28 & 44 & 46 & 48 & 51 & 55 & 58 & 62 & 65 \\
\hline Single-storey basement & & 11 & 23 & 37 & 45 & 51 & 52 & 54 & 57 & 59 & 63 & 65 & 68 \\
\hline $\begin{array}{l}\text { Multi-storey } \\
\text { asement }\end{array}$ & . & 5 & 10 & 17 & 21 & 24 & 26 & 28 & 30 & 33 & 35 & 41 & \\
\hline Multi-storey basement & & 5 & 10 & 16 & 20 & 23 & 24 & 26 & 28 & 30 & 32 & 37 & 43 \\
\hline erent levels & & 5 & 10 & 16 & 19 & 20 & 27 & 34 & 37 & 39 & 44 & 47 & 48 \\
\hline Apartment building & صี & 2 & 5 & 12 & 14 & 15 & 16 & 18 & 19 & 20 & 22 & 23 & 24 \\
\hline partment with basement & & 5 & 11 & 18 & 19 & 21 & 22 & 24 & 25 & 27 & 28 & 35 & 42 \\
\hline
\end{tabular}

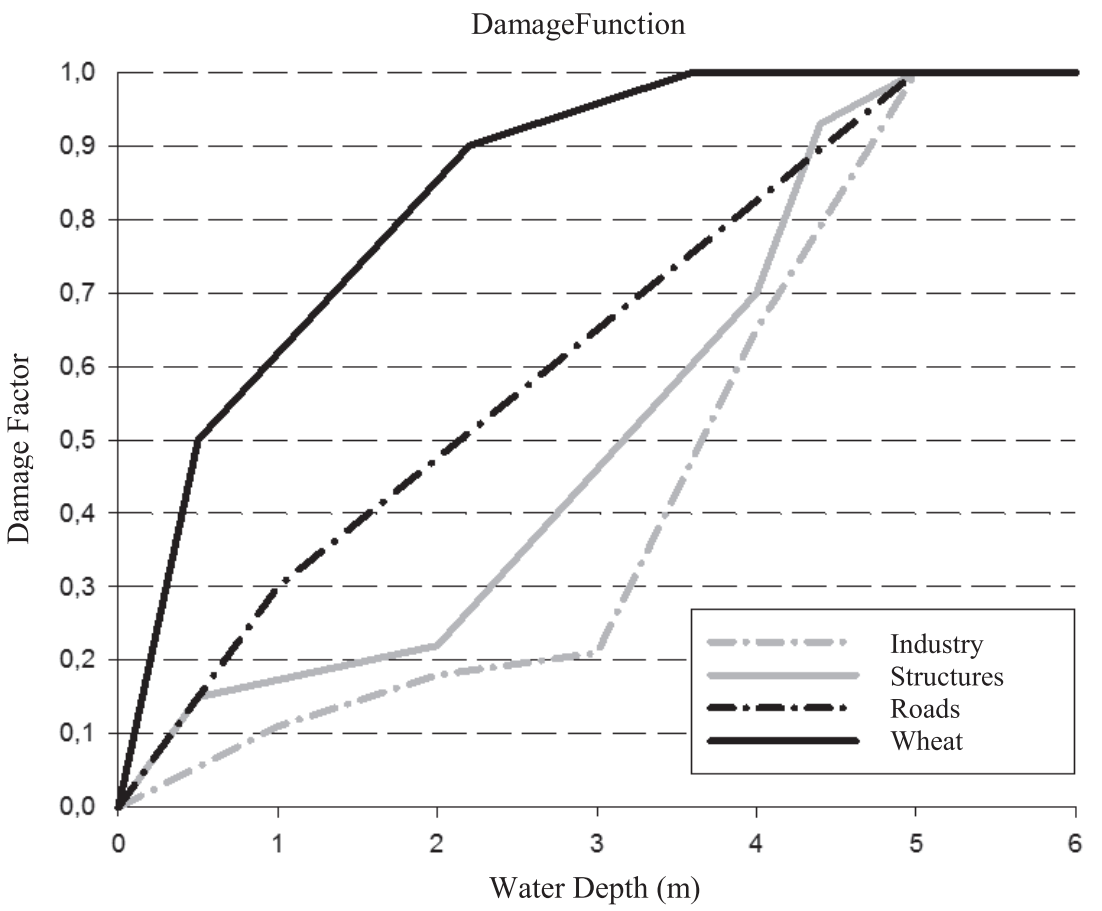

Fig. 2. Depth-loss curves of Van Eck and Kok [16].

\section{Van Eck and Kok's Depth-Loss Curves}

Another method for estimating damage in buildings is the depth-loss curves introduced by Van Eck and Kok and presented in Fig. 2. Here, the type of damage calculation is first determined, and then the damage factor is determined according to the flood depth.

\section{The Equation Obtained by Pistrika and Jonkman}

Pistrika and Jonkman [13] conducted a damage analysis for the houses flooded in New Orleans caused by Hurricane Katrina in 2005. For this analysis, they investigated the relationship between flood characteristics and economic damage by getting public data. Based on those values, they obtained a new equation by using the depth and velocity of the flood to find economic damage.

$$
D=0,457+0,063 d v^{0,654}
$$

Here, D is the flood damage factor (\%), $d$ is the flood depth $(\mathrm{m})$, and $\mathrm{v}$ is the flood velocity $(\mathrm{m} / \mathrm{sec})$. Unlike other methods, flood velocity is also taken into account in this method. 


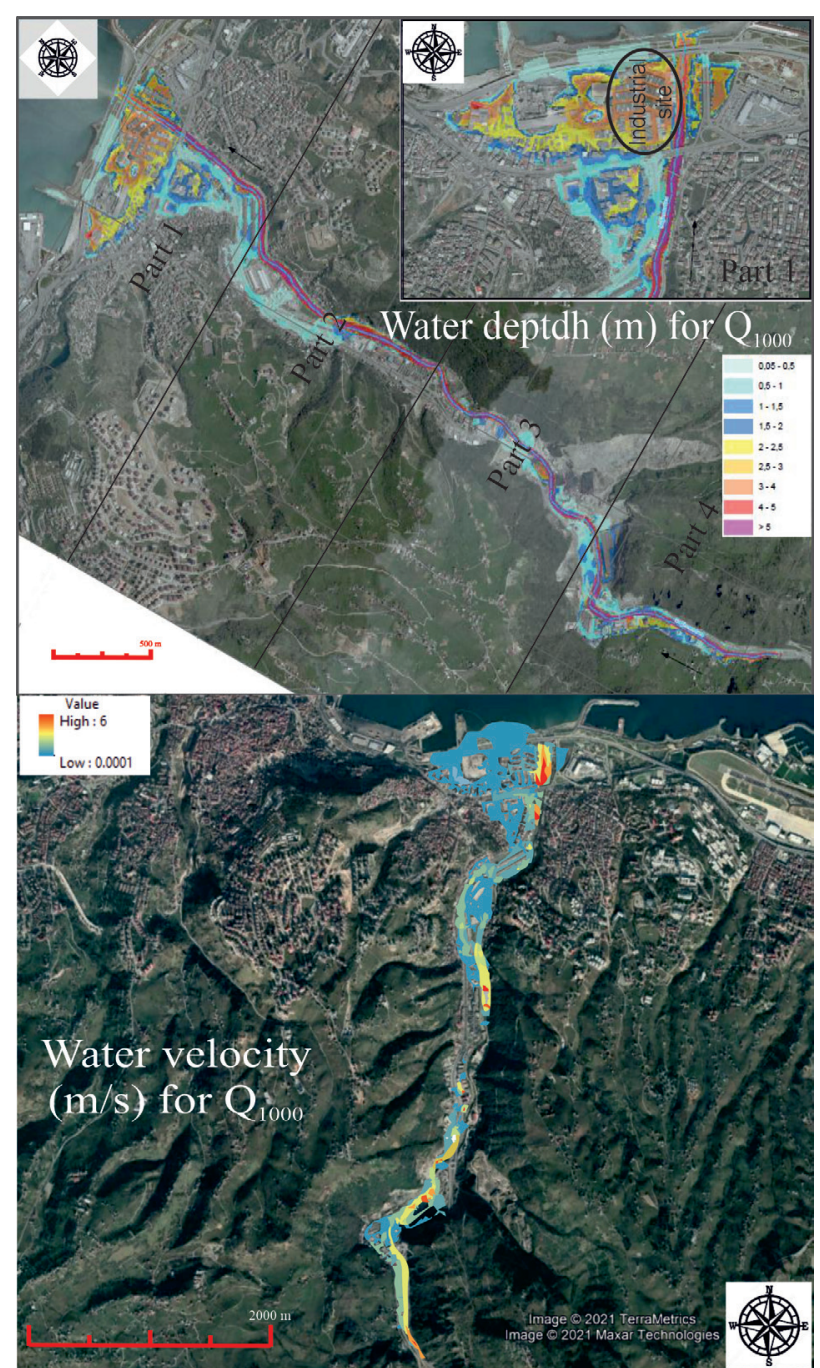

Fig. 3. Değirmendere flood inundation map (for $Q_{1,000}$ ) [27].

\section{Results and Discussion}

The flood inundation and velocity map for $\mathrm{Q}_{1,000}$ of Değirmendere, which was the study area, is presented in Fig. 3 [26]. The study area was divided into 4 parts so that the maps would be visible.

The damage that might occur depending on flood depth and velocity was determined for floods with different return periods in the study area, and the effect of return period duration on damage was examined. As it has been stated previously, since the probable damage is neglected if the depth is below $0.3 \mathrm{~m}$ in the HCEA method, the damage was neglected for the depths below $0.3 \mathrm{~m}$ in all damage calculations performed on a building basis, by considering this method. The depth and velocity values were determined according to flood flow rates with 50, 100, 500, and 1,000-year return periods. There was no building exposed to a depth of more than $0.3 \mathrm{~m}$ for the flow rates with 50 and 100year return periods in the $2^{\text {nd }}$ part and for the flow rates with 50,100, and 500-year return periods in the $3^{\text {rd }}$ part. Therefore, calculations were made only for the flow rate with a 500 and 1,000-year return period in the 2 nd part and for the flow rate with a 1,000-year return period in the 3rd part, and the maps were created. Furthermore, in addition to these studies carried out on a buildingbased, damage calculation was also performed on a regional-based, depending on the average depth and velocity.

For convenience during the examination, Van Eck and Kok's depth-loss curves method was shortened as "Eck," and the amounts of damage calculated by the equation obtained by Pistrika and Jonkman were shortened as "Pistrika".

\section{Results of Building-Based Assessment}

\section{Amounts of Flood Hazards for Flood Discharges with Different Return Periods}

The damage percentages were calculated using the methods selected for each building in the study area, and the estimates of the total amount of damage that would occur in buildings due to the flood of these regions are presented for the three methods in Table 3 according to the unit price list published in the Official Gazette in 2019 [27] and by considering the depreciation as $20 \%$.

In the HCEA method, only the industrial site indicated in Fig. 3 was calculated as single-storey without a basement, all other buildings were considered with a basement.

While the number of floors of buildings that were exposed to the flood was taken into account in the HCEA method, it was not taken into account in the Eck method. However, the amounts of damage obtained by the two methods were found to be close to each other. The amounts of damage calculated by the Pistrika method, in which both flood depth and flood velocity were used, were more than twice the two other methods.

Since depth and velocity increase as return period increases, the amount of damage and the number of buildings affected increase. The increase in the amount of damage is presented both in currency and percentages in Table 4. As is seen in Table 4, in the results obtained by all three methods used, the increase in the amount of damage in the transitions from $\mathrm{Q}_{50}$ to $\mathrm{Q}_{100}$, from $\mathrm{Q}_{100}$ to $\mathrm{Q}_{500}$, and from $\mathrm{Q}_{500}$ to $\mathrm{Q}_{1,000}$ was between $16 \%-30 \%$. The most significant increases were mostly observed in the Pistrika method.

\section{Flood Hazard Rating for Flood Discharges with Different Return Periods}

The damage percentages determined in different return periods were graded according to the methods for the study area. These ratings were only marked on the map taken from Google Earth as a screenshot for the $1^{\text {st }}$ part where the damage was most intense. They are shown in Fig. 4 according to the HCEA method, the Eck method, and the Pistrika method to see the effect of return period durations on damage rate more clearly. 


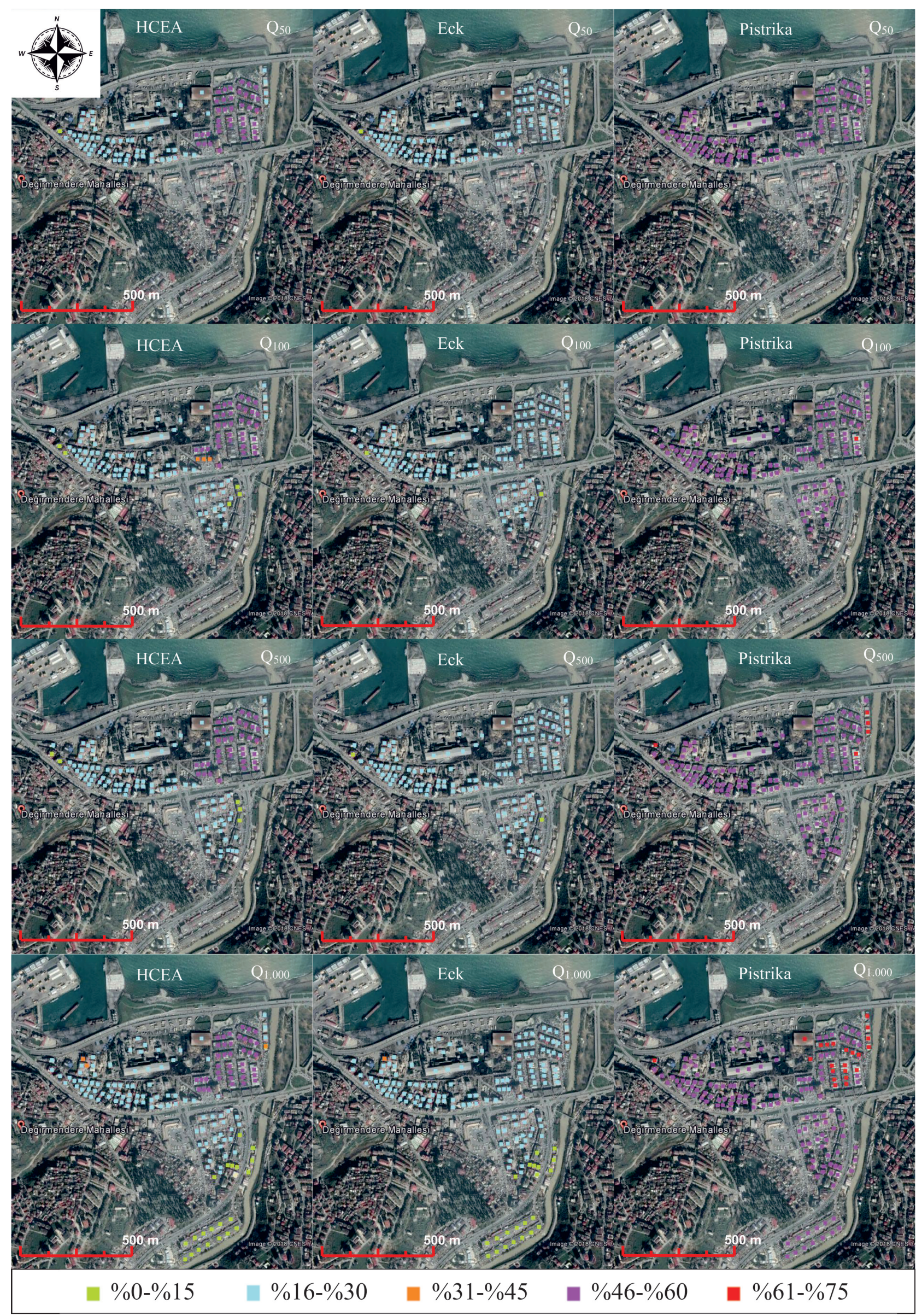

Fig. 4. Flood hazard rating according to the HCEA, Eck and Pistrika method for part 1. 
The return period duration is indicated in the top righthand corner of each map. In these maps, damage rates are marked in green $(0-15 \%)$, blue $(16-30 \%)$, orange (31-45\%), purple (46-60\%), and red (61-75\%).

As is seen in Table 3 , for $\mathrm{Q}_{1,000}$, while damage was in the range of 46 and $60 \%$ in buildings near the side of the stream of the river mouth, the amount of damage decreased in the interior areas, falling to the range of $16-30 \%$ and even to the range of $0-15 \%$ in some places. The region damaged by $46-60 \%$ is the part where the industrial site is located (Fig. 3), and there, the buildings are mostly single-storey. The damage there was found to be significant since this method also takes into account the number of floors. Furthermore, as the return period durations increased, the number of damaged buildings considerably increased in near the stream of the upstream side, especially in the transition from $\mathrm{Q}_{500}$ to $\mathrm{Q}_{1,000}$. The increase in damage rates in buildings along with the increase in the return period duration was not significant.

According to the results obtained by the Eck method, the amount of damage in buildings was usually between $16-30 \%$. There were also buildings damaged in the range of $0-15 \%$, although they were slightly damaged.

Unlike the HCEA method, there was no building damaged in the range of $46-60 \%$ according to this method. It was due to the fact that the number of floors is taken into account in the HCEA method, as has been mentioned previously.

As is seen in Fig. 4, the amount of damage for all buildings calculated in the Pistrika method was more than $45 \%$. Higher damage percentages were generally obtained compared to the other two methods.

While the HCEA method takes into account the number of floors of buildings and whether they have a basement, the Eck method does not take them into account. However, the results were close to each other since damages were calculated based on the flood depth in both methods. However, the Pistrika method includes flood velocity as well as flood depth in calculations. Therefore, the damage results obtained the Pistrika method were different from the other methods.

In order to see the effect of return period duration on damage more clearly, the total floor areas of the buildings exposed to flood and the percentage calculation

Table 2. Damaged building floor areas $\left(\mathrm{m}^{2}\right)$.

\begin{tabular}{|c|c|c|c|c|c|c|c|c|}
\hline & \multirow{2}{*}{$\begin{array}{l}\text { Return } \\
\text { period }\end{array}$} & \multirow{2}{*}{ Method } & \multicolumn{6}{|c|}{ Total damaged building floor areas } \\
\hline & & & All & $0-15 \%$ & $16-30 \%$ & $31-45 \%$ & $46-60 \%$ & $61-75 \%$ \\
\hline \multirow{12}{*}{$1^{\text {stPart }}$} & \multirow{3}{*}{$\mathrm{Q}_{50}$} & HCEA & \multirow{3}{*}{78,805} & 253 & 62,206 & 0 & 16,347 & 0 \\
\hline & & Eck & & 90 & 78,715 & 0 & 0 & 0 \\
\hline & & Pistrika & & 0 & 0 & 0 & 78,805 & 0 \\
\hline & \multirow{3}{*}{$\mathrm{Q}_{100}$} & HCEA & \multirow{3}{*}{94,085} & 2,277 & 75,461 & 800 & 15,547 & 0 \\
\hline & & Eck & & 1,203 & 92,882 & 0 & 0 & 0 \\
\hline & & Pistrika & & 0 & 0 & 0 & 93,575 & 510 \\
\hline & \multirow{3}{*}{$\mathrm{Q}_{500}$} & HCEA & \multirow{3}{*}{100,111} & 7,543 & 76,222 & 0 & 16,347 & 0 \\
\hline & & Eck & & 2,943 & 97,168 & 0 & 0 & 0 \\
\hline & & Pistrika & & 0 & 0 & 0 & 96,990 & 3,121 \\
\hline & \multirow{3}{*}{$\mathrm{Q}_{1,000}$} & HCEA & \multirow{3}{*}{120,004} & 20,807 & 81,406 & 1,444 & 16,347 & 0 \\
\hline & & Eck & & 20,146 & 99,467 & 391 & 0 & 0 \\
\hline & & Pistrika & & 0 & 0 & 0 & 103,447 & 16,557 \\
\hline \multirow{6}{*}{$2^{\text {nd }}$ Part } & \multirow{3}{*}{$\mathrm{Q}_{500}$} & HCEA & \multirow{3}{*}{1,365} & 0 & 1,365 & 0 & 0 & 0 \\
\hline & & Eck & & 0 & 1,365 & 0 & 0 & 0 \\
\hline & & Pistrika & & 0 & 0 & 0 & 1,365 & 0 \\
\hline & \multirow{3}{*}{$\mathrm{Q}_{1,000}$} & HCEA & \multirow{3}{*}{8,650} & 7,285 & 1,365 & 0 & 0 & 0 \\
\hline & & Eck & & 7,093 & 1,557 & 0 & 0 & 0 \\
\hline & & Pistrika & & 0 & 0 & 0 & 8,650 & 0 \\
\hline \multirow{3}{*}{$3^{\text {rd }}$ Part } & \multirow{3}{*}{$\mathrm{Q}_{1,000}$} & HCEA & \multirow{3}{*}{650} & 0 & 650 & 0 & 0 & 0 \\
\hline & & Eck & & 0 & 650 & 0 & 0 & 0 \\
\hline & & Pistrika & & 0 & 0 & 0 & 225 & 425 \\
\hline
\end{tabular}


Table 2. Continued

\begin{tabular}{|c|c|c|c|c|c|c|c|c|}
\hline \multirow{12}{*}{$4^{\text {th }}$ Part } & \multirow{3}{*}{$\mathrm{Q}_{50}$} & HCEA & \multirow{3}{*}{10,410} & 0 & 10,410 & 0 & 0 & 0 \\
\hline & & Eck & & 0 & 10,410 & 0 & 0 & 0 \\
\hline & & Pistrika & & 0 & 0 & 0 & 10,410 & 0 \\
\hline & \multirow{3}{*}{$\mathrm{Q}_{100}$} & HCEA & \multirow{3}{*}{15,447} & 5,037 & 10,410 & 0 & 0 & 0 \\
\hline & & Eck & & 2,610 & 12,837 & 0 & 0 & 0 \\
\hline & & Pistrika & & 0 & 0 & 0 & 15,447 & 0 \\
\hline & \multirow{3}{*}{$\mathrm{Q}_{500}$} & HCEA & \multirow{3}{*}{22,509} & 6,388 & 16,121 & 0 & 0 & 0 \\
\hline & & Eck & & 1,947 & 20,562 & 0 & 0 & 0 \\
\hline & & Pistrika & & 0 & 0 & 0 & 19,216 & 3,293 \\
\hline & \multirow{3}{*}{$\mathrm{Q}_{1,000}$} & HCEA & \multirow{3}{*}{26,822} & 8,884 & 17,410 & 528 & 0 & 0 \\
\hline & & Eck & & 3,395 & 23,133 & 294 & 0 & 0 \\
\hline & & Pistrika & & 0 & 0 & 0 & 15,564 & 11,258 \\
\hline \multirow{12}{*}{ All Parts } & \multirow{3}{*}{$\mathrm{Q}_{50}$} & HCEA & \multirow{3}{*}{89,215} & 253 & 72,615 & 0 & 16,347 & 0 \\
\hline & & Eck & & 90 & 89,125 & 0 & 0 & 0 \\
\hline & & Pistrika & & 0 & 0 & 0 & 89,215 & 0 \\
\hline & \multirow{3}{*}{$\mathrm{Q}_{100}$} & HCEA & \multirow{3}{*}{109,532} & 7,314 & 85,871 & 800 & 15,547 & 0 \\
\hline & & Eck & & 3,813 & 105,719 & 0 & 0 & 0 \\
\hline & & Pistrika & & 0 & 0 & 0 & 109,021 & 511 \\
\hline & \multirow{3}{*}{$\mathrm{Q}_{500}$} & HCEA & \multirow{3}{*}{123,984} & 13,931 & 93,706 & 0 & 16,347 & 0 \\
\hline & & Eck & & 4,890 & 119,094 & 0 & 0 & 0 \\
\hline & & Pistrika & & 0 & 0 & 0 & 117,571 & 6,413 \\
\hline & \multirow{3}{*}{$\mathrm{Q}_{1,000}$} & HCEA & \multirow{3}{*}{156,126} & 36,976 & 100,831 & 1,972 & 16,347 & 0 \\
\hline & & Eck & & 30,633 & 124,809 & 684 & 0 & 0 \\
\hline & & Pistrika & & 0 & 0 & 0 & 127,886 & 28,240 \\
\hline
\end{tabular}

chart of these floor areas according to the methods used are presented in Table 2 and Fig. 5 separately for each part and as the sum of all parts. The percentages were calculated by considering the sum of the floor areas of the buildings exposed to flood as $100 \%$ in the case of $\mathrm{Q}_{1,000}$. Since there was damage only when it was $\mathrm{Q}_{1,000}$ in $3^{\text {th }}$ part, it was not presented in Fig. 5.

As is seen in Table 2 and Fig. 5, the effect of the amount of flood return period on damage rates was quite high. In the $1^{\text {st }}$ part, there was a damage increase of $19 \%$ in $\mathrm{Q}_{100}$, a $27 \%$ increase in $\mathrm{Q}_{500}$, and a $52 \%$ increase in $\mathrm{Q}_{1,000}$ compared to $\mathrm{Q}_{50}$ based on the building floor area. When the floor areas of the damaged buildings were considered, the damage rates varied by the return period duration, and there were decreases in the percentage values of damage rates as the return period duration decreased. In the $2^{\text {nd }}$ part, the number of buildings damaged both in $\mathrm{Q}_{500}$ and $\mathrm{Q}_{1,000}$ was quite low compared to other parts. In $\mathrm{Q}_{50}$ and $\mathrm{Q}_{100}$, there was no damaged building. However, in the $1^{\text {st }}$ part, the building with a total floor area of $78,805 \mathrm{~m}^{2}$ for $\mathrm{Q}_{50}$ was calculated to be damaged. In the $3^{\text {rd }}$ part where the least damage occurred, the building with a total floor area of $650 \mathrm{~m}^{2}$ was damaged only when it was $\mathrm{Q}_{1.000}$. For the 4th part, flood hazards were higher in $\mathrm{Q}_{100}$ by $48 \%$, in $\mathrm{Q}_{500}$ by $116 \%$, and in $\mathrm{Q}_{1.000}$ by $157 \%$ compared to $\mathrm{Q}_{50}$. It was the most damaged area after the 1st part. When the whole region was considered, it appeared that the area exposed to the flood was higher in $\mathrm{Q}_{100}$ by $23 \%$, in $\mathrm{Q}_{500}$ by $39 \%$, and in $\mathrm{Q}_{1,000}$ by $75 \%$ compared to $\mathrm{Q}_{50}$.

In other words, the location of the region and the amount of settlement also appeared to be major factors in the flood hazard calculation, indicating that the selection of settlements in and around stream beds is quite essential in terms of flood hazard.

\section{Region-Based Assessment Results}

The damage percentages obtained according to the average depth and velocity in different recurrence flows by the methods selected were multiplied by the total building floor areas in the entire study area. Afterward, 

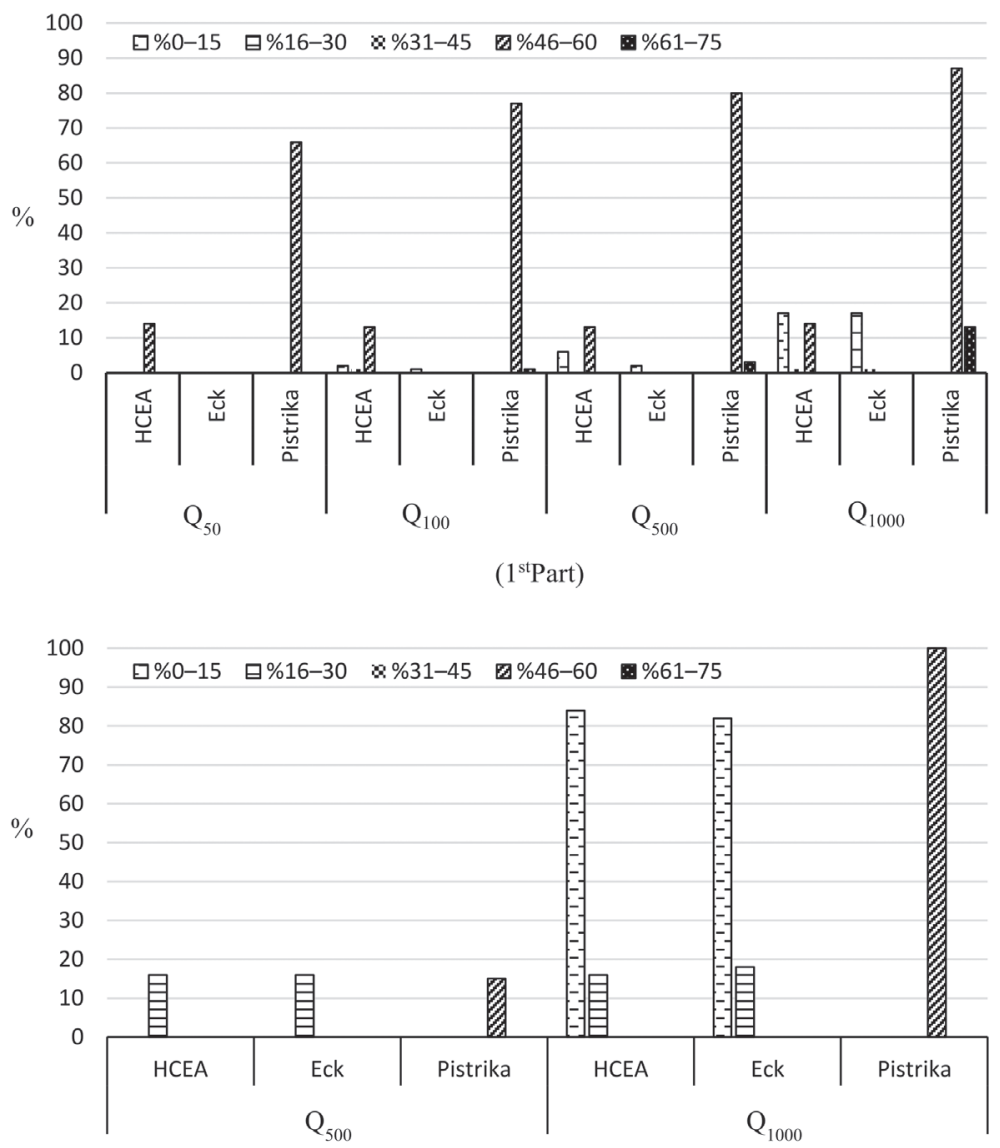

( $2^{\text {stPart })}$

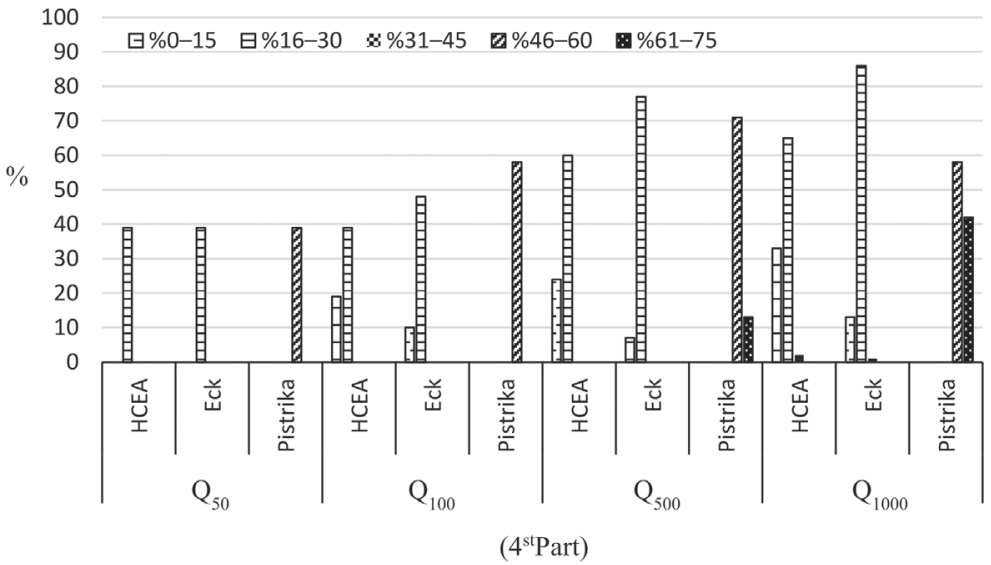

Fig. 5. Percentages of damaged building floor areas.

these values were multiplied by the unit price [27] and depreciation (20\%), and the estimated building damage amounts were obtained regionally and presented in Table 3.

In the results obtained by the HCEA method, there was $63 \%$ more damage in $\mathrm{Q}_{100}, 233 \%$ more damage in $\mathrm{Q}_{500}$, and $299 \%$ more damage in $\mathrm{Q}_{1,000}$ compared to $\mathrm{Q}_{50}$. In the results obtained by the Eck method, there was $63 \%$ more damage in $\mathrm{Q}_{100}, 220 \%$ more damage in $\mathrm{Q}_{500}$, and $275 \%$ more damage in $\mathrm{Q}_{1.000}$ compared to $\mathrm{Q}_{50}$. In the results obtained by the Pistrika method, there was
$30 \%$ more damage in $\mathrm{Q}_{100}, 71 \%$ more damage in $\mathrm{Q}_{500}$, and $73 \%$ more damage in $\mathrm{Q}_{1,000}$ compared to $\mathrm{Q}_{50}$.

\section{The Comparison of the Model Results}

The difference between the amounts of damage that would occur on the basis of buildings and regions in flow rates with different return periods is presented in Table 3. As is seen in Table 3, quite different results were obtained in flood hazard calculations on the basis of region and building. The rates of change between 
the amounts of damage determined in different return periods were also different. For example, when it was $\mathrm{Q}_{1.000}$, the amount of damage calculated on a building basis was $154 \%$ higher by the HCEA method and $17 \%$ higher by the Eck method compared to region-based calculation. It was $11 \%$ lower in the Pistrika method. When it was $\mathrm{Q}_{500}$, the amount of damage calculated on the building-based was $153 \%$ higher by the HCEA method and $10 \%$ higher by the Eck method compared to region-based calculation. It was $30 \%$ lower in the Pistrika method. The amounts of damage obtained based on the depth in the HCEA and Eck methods for the study area were found to be lower in the regionbased calculation compared to the building-based calculation. Furthermore, the most significant difference was obtained according to the HCEA method. There was much less difference in the Eck method because the number of floors and the presence of the basement are not taken into account in the HCEA method. In other words, the number of floors of buildings exposed to flood and whether they have a basement are also important parameters affecting the damage. The amounts of damage obtained by the Pistrika method, in which both the flood depth and velocity are used, were found to be high in the region-based calculation compared to the building-based calculation. It was due to the fact that the flood depth that the buildings were exposed to was higher than the average depth and that the flood velocity was smaller than the average velocity.

The parameters used in the calculation of the amounts of flood hazard were also quite effective on the results obtained. The results obtained by the HCEA and Eck methods depending on the flood depth in both building-based and regional-based calculations were very close to each other. However, with the Pistrika method in which velocity was used in addition to depth, it appeared that quite different increase values were obtained when the monetary values of the damages, the damage rates of the affected buildings, and the increasing amounts of damages as the return period increased were examined (Tables 2-4). In addition to these, the difference calculated in the three method did not change proportionally with the return periods (Table 4). Furthermore, while the increase between $\mathrm{Q}_{500}$ and $\mathrm{Q}_{1,000}$ in the building-based calculation was $20 \%$ in the HCEA method and $25 \%$ in the Eck method, this difference increased to $28 \%$ in the Pistrika method in which depth, as well as velocity, was taken into account. The Pistrika method, which also takes into account the velocity in building-based evaluation, increases the sensitivity of the calculation performed for flow rates with different return periods. However, in the region-based assessment, while the increase between $\mathrm{Q}_{500}$ and $\mathrm{Q}_{1,000}$ was obtained to be $20 \%$ in the HCEA method and $17 \%$ in the Eck method, it was calculated to be $1 \%$ in the Pistrika method. As with the amounts of damage, the increase rates depending on the change of return period are also obtained as close to each other by the HCEA and Eck methods, and they are obtained differently by the Pistrika method.

In the region-based calculation, it was considered that all buildings in the area were exposed to floods,

Table 3. Flood hazard amounts on the basis of region and building for the study area (USD, at 2019 prices).

\begin{tabular}{|c|c|c|c|c|}
\hline Return period & Account Type & HCEA & Eck & Pistrika \\
\hline \multirow{4}{*}{$\mathrm{Q}_{50}$} & By region & 534,000 & $1,089,000$ & $7,715,000$ \\
\hline & By building & $3,240,000$ & $2,583,000$ & $6,064,000$ \\
\hline & Difference & $2,706,000$ & $1,495,000$ & $1,652,000$ \\
\hline & Change (\%) & 507 & 137 & -21 \\
\hline \multirow{4}{*}{$\mathrm{Q}_{100}$} & By region & 869,000 & $1,773,000$ & $10,021,000$ \\
\hline & By building & $3,879,000$ & $3,208,000$ & $7,888,000$ \\
\hline & Difference & $3,010,000$ & $1,436,000$ & $2,133,000$ \\
\hline & Change (\%) & 346 & 81 & -21 \\
\hline \multirow{4}{*}{$\mathrm{Q}_{500}$} & By region & $1,776,000$ & $3,483,000$ & $13,160,000$ \\
\hline & By building & $4,492,000$ & $3,819,000$ & $9,274,000$ \\
\hline & Difference & $2,716,000$ & 335,000 & $3,887,000$ \\
\hline & Change (\%) & 153 & 10 & -30 \\
\hline \multirow{4}{*}{$\mathrm{Q}_{1000}$} & By region & $2,131,000$ & $4,087,000$ & $13,325,000$ \\
\hline & By building & $5,409,000$ & $4,785,000$ & $11,873,000$ \\
\hline & Difference & $3,278,000$ & 698,000 & $1,453,000$ \\
\hline & Change (\%) & 154 & 17 & -11 \\
\hline
\end{tabular}


Table 4. Increase in damage according to return period duration.

\begin{tabular}{|c|c|c|c|c|c|}
\hline Study & \multicolumn{2}{|c|}{ Study area } & Method & Return period & Increase $(\%)$ \\
\hline \multirow{18}{*}{ This study } & \multirow{18}{*}{ Değirmendere } & \multirow{9}{*}{ By building } & HCEA & \multirow{3}{*}{$\mathrm{Q}_{50}-\mathrm{Q}_{100}$} & 20 \\
\hline & & & Eck & & 24 \\
\hline & & & Pistrika & & 30 \\
\hline & & & HCEA & & 16 \\
\hline & & & Eck & $\mathrm{Q}_{100}-\mathrm{Q}_{500}$ & 19 \\
\hline & & & Pistrika & & 18 \\
\hline & & & HCEA & & 20 \\
\hline & & & Eck & $\mathrm{Q}_{500}-\mathrm{Q}_{1,000}$ & 25 \\
\hline & & & Pistrika & & 28 \\
\hline & & & HCEA & & 63 \\
\hline & & & Eck & $\mathrm{Q}_{50}-\mathrm{Q}_{100}$ & 63 \\
\hline & & & Pistrika & & 30 \\
\hline & & & HCEA & & 104 \\
\hline & & By region & Eck & $\mathrm{Q}_{100}-\mathrm{Q}_{500}$ & 97 \\
\hline & & & Pistrika & & 31 \\
\hline & & & HCEA & & 20 \\
\hline & & & Eck & $\mathrm{Q}_{500}-\mathrm{Q}_{1,000}$ & 17 \\
\hline & & & Pistrika & & 1 \\
\hline Serencam & & & Eck & & 47 \\
\hline (2013) & & & Moel and Aerts & $Q_{100} Q_{500}$ & 67 \\
\hline $\begin{array}{l}\text { Girayhan } \\
\text { (2015) }\end{array}$ & Terme & By region & $\begin{array}{c}\text { Functions produced byAmerican Army } \\
\text { Engineering }\end{array}$ & $\mathrm{Q}_{100}-\mathrm{Q}_{500}$ & 12 \\
\hline $\begin{array}{l}\text { Taş et al. } \\
(2016)\end{array}$ & $\begin{array}{l}\text { Akarçay, Afyon } \\
\text { Lower Basin }\end{array}$ & By region & $\begin{array}{l}\text { Jonkman et al. (2008) obtained } \\
\text { by the damage function }\end{array}$ & $\mathrm{Q}_{100}-\mathrm{Q}_{500}$ & 50 \\
\hline
\end{tabular}

and in general, the average amount of damage was obtained. However, in the building-based calculation, the calculation was performed individually for buildings that were exposed to flood depending on the recurrence flow, and the damage amount of each building was calculated separately. In conclusion, the use of building-based damage calculation is considered to be more appropriate in flood hazard calculations in order to obtain more precise results and to determine the order of priority of buildings that can be damaged.

\section{Evaluation of the Effect of Return Period Duration on Flood Hazard}

The percentage increase amounts of damages were obtained from both this study and previous studies carried out in Turkey for the evaluation of the effect of return period duration on the amounts of damage (Table 4).
As is seen in Table 4, the damage increased as the return period duration increased. According to the flood hazard estimation calculated based on the return period duration, it is necessary to plan the land use in the area to be flooded, to select and project the flood structure that needs to be built, and to determine flood investments. Therefore, it is essential to determine which return period duration will be taken into consideration. Especially in building-based calculations, there were significant differences between the amount of damages estimated for $\mathrm{Q}_{500}$ and $\mathrm{Q}_{1,000}$. For example, the estimated amount of damage to be considered while building a flood protection structure in the study area will increase by $20-28 \%$ in case of using $Q_{500}$ instead of $\mathrm{Q}_{1,000}$ according to the building-based calculation obtained in this study. The flood recurrence flow will be on the safer side when $Q_{1,000}$ is selected instead of $\mathrm{Q}_{500}$. However, the cost of the flood structure to be built accordingly will increase. 


\section{Conclusions}

The aim of this study is to investigate the effect of building-based assessment. For this purpose, the depth and velocity of floods that would affect each building at flow rates with different return periods in Değirmendere Stream, Eastern Black Sea Basin, Turkey, were determined, and building-based flood hazard calculations were performed and the damage rates were rated. The levels of damage of each building in the area where the damage was intense in the region were shown on the map. Furthermore, the difference between the region-based flood hazard calculations performed based on the average flood depth and velocity was examined. The HCEA, Eck, and Pistrika methods were used for damage calculations.

The main results obtained from this study are as follows:

- In the flood hazard calculations performed on the basis of region and building, the amounts of damage obtained with the HCEA and Eck methods depending on the depth for the study area were found to be quite low compared to the building-based calculation in the region-based calculation. The amounts of damage obtained by the Pistrika method, in which both flood depth and flood velocity are used, were higher compared to the building-based calculation in the region-based calculation. It was due to the fact that the depth of floods to which buildings were exposed on streets was higher than the average depth and that the flood velocity was less than the average velocity.

- The results obtained by building-based and regionbased calculations were quite different. Therefore, it was concluded that it would be more appropriate to perform the building-based calculation in order to obtain more precise results in building damage calculations and to determine the order of priority of buildings that can be damaged to take precautions.

- Since water depth increases as the return period duration of flood flow rates increases, the number of buildings at risk and thus the number of damaged buildings, the rate of damage incurred, and the monetary equivalent of the amount of damage increase. Furthermore, the damage is at a negligible level in some areas, especially in low return period durations. Therefore, the location of the region and the size of the settlement should be taken into account while determining the return period duration in the selection of the project flow for a flood structure to be built.

- The differences between the results obtained by each method were not proportional to the change in the amount of recurrence flood.

- According to damage calculations, the amount of increase from $\mathrm{Q}_{50}$ to $\mathrm{Q}_{100}$, from $\mathrm{Q}_{100}$ to $\mathrm{Q}_{500}$, and from $\mathrm{Q}_{500}$ to $\mathrm{Q}_{1,000}$ was observed to be between $16 \%$ and $30 \%$.
- When the recurrence flood is selected to be large, a more precise calculation will be made and more significant measures will be taken. However, the cost of the flood structure to be built accordingly will increase. Therefore, it is essential to determine the return period amounts.

- Since the HCEA method includes different parameters such as the number of floors and the presence of a basement, it provides a more detailed evaluation than the Eck method. Nevertheless, the amount of damage and the degrees of damage obtained in the HCEA and Eck methods were close to each other. The amounts of damage greater than two times were obtained by the Pistrika method compared to the HCEA and Eck methods.

- The increase between $\mathrm{Q}_{500}$ and $\mathrm{Q}_{1,000}$ was $20 \%$ in the HCEA method, $25 \%$ in the Eck method, and $28 \%$ in the Pistrika method in the building based calculation. In the regional calculation, it was $20 \%$ in the HCEA method, $17 \%$ in the Eck method, and $1 \%$ in the Pistrika method. As the amount of damage, the amounts of the increase in damages depending on the return period were close to each other in the HCEA and Eck methods and quite different in the Pistrika method.

- The determination of the parameters that can be obtained and that should be used during flood hazard estimation and the choice of a method accordingly are quite important.

\section{Acknowledgments}

We would like to thank Dr. Emre AKÇALI, General Directorate of State Hydraulic Works (DSI), for providing hydrological data, all employees in DSI Trabzon Regional Directorate, and Bora TURAN, NFB Company Manager.

\section{Conflict of Interest}

The authors declare no conflict of interest.

\section{References}

1. DAVIS S.A., SKAGGS L.L. Catalog of Residential DepthDamage Functions Used by the Army Corps of Engineers in Flood Damage Estimations, U.S. Army Corps of Engineers, Virginia, 1992.

2. GREEN C.H. The Handbook of Water Economics: Principles and Practice, John Wiley \& Sons Ltd., Chichester, 2003.

3. SAMPSON C.C., SMITH A.M., BATES P.D., NEAL J.C., ALFIERI L., FREER J.E. Water Resources Research, Water Resour. Res. 7358, 2015. https://doi. org/10.1002/2015WR016954.Received.

4. APEL H., THIEKEN A.H., MERZ B. A Probabilistic Modelling System for Assessing Flood Risks, Nat. 
Hazards. 38，79, 2006. https://doi.org/10.1007/s11069-0058603-7.

5. PRETTENTHALER F., AMRUSCH P., POLICY R., CHANGE G. Estimation of an absolute flood damage curve based on an Austrian case study under a dam breach scenario, Nat. Hazards Earth Syst. Sci. 10, 881, 2010.

6. DE MOEL H., AERTS J.C.J.H. Effect of uncertainty in land use, damage models and inundation depth on flood damage estimates, Nat. Hazards. 58, 407, 2011. https://doi. org/10.1007/s11069-010-9675-6.

7. JONGMAN B., KREIBICH H., APEL H., BARREDO J.I., BATES P.D., FEYEN L., GERICKE A., NEAL J. Comparative flood damage model assessment: towards a European approach, Nat. Hazards Earth Syst. Sci. 12, 3733, 2012. https://doi.org/10.5194/nhess-12-3733-2012.

8. CAMMERER H., THIEKEN A.H., LAMMEL J. Adaptability and transferability of flood loss functions in residential areas, Nat. Hazards Earth Syst. Sci. 13, 3063, 2013. https://doi.org/10.5194/nhess-13-3063-2013.

9. NOTARO V., DE MARCHIS M., FONTANAZZA C.M., LA LOGGIA G., PULEO V., FRENI G. The effect of damage functions on urban flood damage appraisal, Procedia Eng. 70, 1251, 2014. https://oi.org/10.1016/j. proeng.2014.02.138.

10. PISTRIKA A., TSAKIRIS G., NALBANTIS I. Flood Depth-Damage Functions for Built Environment, Environ. Process. 1, 553, 2014. https://doi.org/10.1007/s40710-0140038-2.

11. MCGRATH H., STEFANAKIS E., NASTEV M. International Journal of Disaster Risk Reduction Sensitivity analysis of fl ood damage estimates: A case study in Fredericton, New Brunswick, Int. J. Disaster Risk Reduct. 14, 379, 2015. https://doi.org/10.1016/j. ijdrr.2015.09.003.

12. KREIBICH H., PIROTH K., SEIFERT I., MAIWALD H., KUNERT U., SCHWARZ J., MERZ B., THIEKEN A.H. Is flow velocity a significant parameter in flood damage modelling? Nat. Hazards Earth Syst. Sci. 9, 1679, 2009.

13. PISTRIKA A.K., JONKMAN S.N. Damage to residential buildings due to flooding of New Orleans after hurricane Katrina, Nat. Hazards. 54, 413, 2010. https://doi. org/10.1007/s11069-009-9476-y.

14. LEE E.H., KIM J.H. Development of a fl ood-damagebased fl ood forecasting technique, J. Hydrol. 563, 181, 2018. https://doi.org/10.1016/j.jhydrol.2018.06.003.
15. ZIN W.W., KAWASAKI A., TAKEUCHI W., MAR Z. TIN L., HTUN K.Z., AYE T.H., WIN S. Flood Hazard Assessment of Bago River Basin, Myanmar, J. Disaster Res. 13, 14, 2018.

16. SERENCAM U. Analysis of Flood Damages and Vulnerability: A Case Study On Sanayi Sanayi District in Değirmendere, Trabzon, Karadeniz Technical University, 2013 [In Turkish].

17. YEĞIN M. Flood Risk Mapping Using Economic, Environmental and Social Dimensions, The Middle East Technical University, 2015.

18. GIRAYHAN T.F. Development of Methodology and Damage Modeling By Quantic Flood Risk Assessment, Ankara, 2015.

19. TAS E., İÇĂGA Y., ZORLUER İ. Constitution of Flood Inundation Maps and Flood Damage Analysis: A Case Study of Akarcay Afyon Subbasin, Afyon Kocatepe Univ. J. Sci. Eng. 16, 711, 2016. https://doi.org/10.5578/ fmbd.27767.

20. ÖZMEN M.T. Flood Turkey and Antalya, Antalya, Kutlu\&Avc1 Offset. 2015.

21. SÜME V., TANSEL B., GÜNER M.S. Suggestions for Reducing the Effects and Damages of Floods in the Eastern Black Sea Region, in: Proc. Int. Symp. Nat. Hazards Hazard Manag. 2, 2016 [In Turkish].

22. VAN ECK N.V., KOK M. Standard Methode Schade en Slacht offers Als Gevolg Van Overstromingen, DienstWegen Waterbouwkunde, Ministerievan Rijkswaterstaat, Netherlands, 2001.

23. KARSTARLI Ç., KÖMÜRCÜ M.İ., AKPINAR A., UZLU E., KANKAL M., ÖNSOY H. Analysis Of Hydroelectric Potential in the Eastern Black Sea Basin, in: $2^{\text {nd }}$ Water Struct. Symp. Diyarbakır, Turkey: 129, 2011 [In Turkish].

24. Akçay F. Trend Analysis for the Monthly And Yearly Mean Flows of the Eastern Black Sea Basin, Karadeniz Technical University, 2018 [In Turkish].

25. TAS E. Basin Planning And Management: a Case Study of Trabzon Degirmendere Basin, Karadeniz Technical University, 2014 [In Turkish].

26. NBF Engineering and Consultancy, 22. Region Trabzon Province Flood Hazard Areas Report and Engineering Services Construction Work Hydrology Planning Report, Trabzon, 2014 [In Turkish].

27. Official Gazette (30716), Available from https://www. resmigazete.gov.tr/eskiler/2019/03/20190316-12.htm, 2019 [In Turkish]. 